\title{
Standardization of Temperature for Effective Germination of Tomato Seeds Using Drum Dryer
}

\author{
Perugu Balachandra Yadav ${ }^{1 *}$, Guda Prasanna ${ }^{2}$, Gadhe Shruthi ${ }^{3}$ and A. Srinivasa Rao ${ }^{4}$ \\ ${ }^{1}$ ICAR-Indian Agricultural Research Institute, New Delhi, India \\ ${ }^{2}$ College of Agricultural Engineering, Bapatla, India \\ ${ }^{3}$ Institute of Agri Business Management, Rajasthan, India \\ ${ }^{4}$ College of Agricultural Engineering, Madakasira, India
}

*Corresponding author

\section{Keywords \\ Standardisation, Temperature, drying, Germination \\ Article Info \\ Accepted: \\ 06 August 2018 \\ Available Online: \\ 10 September 2018}

\section{A B S T R A C T}

The vegetable seeds were dried using the drum dryer to reduce the moisture to improve storage period as well as to maintain good germination. The seeds were treated with TSP (Tri sodium phosphate solution) and calcium hypo chloride solution to protect from seed borne or soil borne diseases. The seeds having both viral and bacterial diseases, then it is treated with the both TSP and calcium hypo chloride solutions. The different varieties of tomato seeds like Montage, Mighty, Naina and Aruna were taken and each sample were subjected to sanitation process before drying for conducting experiments. The standard $\mathrm{RH}$ of $25 \%$ was maintained inside the dryer. The experiments were conducted to study the nature of drying of different samples maintaining different temperatures such as $32^{\circ} \mathrm{C}$, $34^{\circ} \mathrm{C}, 36^{\circ} \mathrm{C}$ and $38^{\circ} \mathrm{C}$. The dried tomato seed samples were stored for 15 days and germination percentage of each samples were analysed. The higher germination percentage was observed around $(86 \%, 90 \%, 97 \%$ and 93\%) in all varieties dried at higher temperature of $38^{\circ} \mathrm{C}$ whereas lower germination percentage was around $(74 \%, 85 \%, 86 \%$ and $84 \%$ ) at low temperature of $32^{\circ} \mathrm{C}$. The effective drying of tomato seeds using drum dryer was maintained at $\mathrm{RH}$ of $25 \%$ and temperature of $38^{\circ} \mathrm{C}$ in order to obtain better storage and good germination.

\section{Introduction}

The quality of seed is considered as an important factor for increasing yield. The use of quality seeds helps greatly in higher production per unit area to attain food security of the country. Quality seeds have the ability of efficient utilization of inputs such as fertilizers and irrigation. Quality seed is defined as varietally pure with high germination percentage, free from disease and disease organisms, and with proper moisture content and weight (Mirza Hasanuzzaman, 2015).

The tomato is one of the most scientifically investigated vegetables because of its commercial importance. The vegetable is highly perishable and the post-harvest losses are around 25 to $50 \%$ (Sacilik, 2007). In tropical countries, it was found that around $20-50 \%$ of post-harvest loss from harvesting 
to consumption (De Souza et al., 2002, George et al., 2011, Aworth et al., 1981). Tomato fruit presents high water content, 9395\% (Shi and M. Le Maguer, 2000). It is low in calories and rich in vitamins $\mathrm{A}, \mathrm{C}$, and $\mathrm{E}$ and minerals such as calcium, potassium, and phosphorus. In a rank of 10 vitamins and minerals, tomato is the first in terms of contribution in the diet (Khachik et al., 2002; Vinson et al., 1998).

Drying is the most important processing operation for better quality of seeds. The seeds which are received from farmers have high initial moisture: to reduce the moisture level for better storage the drying should be done (Ekechukwu and Norton, 1999). Drying can be done by two methods. 1. Natural dryingdrying the seeds by means of sunlight as a source. 2. Artificial drying-drying can be done by using different types of dryers. Now-a-days for efficient drying of seeds dryers are used as natural calamities may not effect as it affects the natural drying (Pirasteh et al., 2014).

Drying process represents one of the earliest techniques used to process fruit and vegetables. More advanced drying methods such as the use of artificial dryers have been developed which ensure greater control over the drying process, have greater capacity and enable a wider range of products to be dried. However there are some disadvantages to artificial dryers. Artificial drying requires greater capital investment as production costs are higher owing to fuel, equipment spares and maintenance costs.

In spite of that, a rising attention to the production of dried tomatoes is clear owing to the several ways their use and cooking (Mcminn and Magee, 1999). Therefore, there is a rising demand by the consumer of finished products having their nutritional and sensorial characteristics preserved as much as possible. The experimental and industrial research turns its attention to optimization of the tomato drying process (Carcel et al., 2007; Clemente et al., 2007; Riahi et al., 2007 and Nogaya et al., 2006). Many papers on single method dehydration have been published recently (Hernandez-Perez et al., 2004; Brunetti et al., 2004; Correa et al., 2012 and Khalifa, et al., 2012).

The drum dryer considered for this experiment was imported from Holland drying of vegetable seeds.

The key to success in seed broadcasting is proper timing of germination, where the period of germination is prolonged, the emerging seedling is exposed to risk of attack by soil microbes or lack of sufficient moisture, light or oxygen (Sabongari and Aliero, 2003.). The idea of soaking seeds before sowing is aimed at shortening the lag phase in germination and to enhance seedling establishment thereby minimizing the risk in the early vegetative growth Hence, the aim of this study is to standardise the temperature of tomato seed for good germination without affecting quality and identify the most effective soaking period for germination, growth and development of tomato seedlings.

\section{Materials and Methods}

\section{Raw materials}

The tomato seeds of different varieties (Montage, Mighty, Naina and Aruna) for conducting research were collected from Karnataka and Maharashtra. The seeds were separated from the tomato after harvesting and subsequently subjected to drying the fruit in the sunshade. Tomato seeds of different varieties are taken from the field for determination of germination percentage of the seeds. Seeds are treated with chemicals (Tri sodium phosphate solution and calcium hypo chloride solution) by sanitation process 
for removal of virus, bacteria and fungus before germination. After sanitation process, spin dryer is used for removal of water from the tomato seeds and reducing drying time during this process.

\section{Drying using drum dryer}

The drying chamber consists of seed drying unit which is made of insulated panels. In between these panels it consists of two-sided galvanised steel sheet with $80 \mathrm{~mm}$ insulation boards. The dryer has two compartments and each compartment is having arrangement of rotational drying unit. The rotation unit is made of two different layers. Each layer has its own air channel. One air channel has three outlets which are split-up into different three parts. The air gap of each part can be adjusted and closed by means of a valve. The number of rotations of the drying drums will be controlled using frequency control.

The selected samples of different varieties (Montage, Mighty, Naina and Aruna) after sanitation process were subjected to drying using drum dryer. The standard relative humidity of $25 \%$ is fixed in the drum dryer. Later, the nature of drying of different samples at different temperatures $\left(32^{\circ} \mathrm{C}, 34^{\circ} \mathrm{C}, 36^{\circ} \mathrm{C}\right.$ and $38^{\circ} \mathrm{C}$ ) were studied. Initially the wet tomato seeds after sanitation are inserted into seed drums and passed to rotation unit, where seeds are subjected to rotation in drums. This prevents seeds from sticking from each other when undergoing continuous movement.

\section{Determination of germination percentage}

Different varieties of tomato, around 100 seeds of each sample were taken along with two replications and the germination test for the tomato seeds was conducted before and after drying (paper towel method) using drum dryer to determine the quality aspects of the dried tomato seeds.

\section{Germination percentage formula}

Germination percentage is an estimate of the viability of a population of seeds. The equation to calculate germination percentage is:

$$
\mathrm{GP}=\text { seeds germinated/total seeds } \mathrm{x} 100 \text {. }
$$

The germination rate provides a measure of the time course of seed germination

\section{Results and Discussion}

Effect of drying temperature on germination percentage in montage variety seeds

The germination percentage of $86 \%$ was recorded to be highest after storage of samples for 15 days at drying temperature of $38^{\circ} \mathrm{C}$.

The germination percentages at different temperatures like $36^{\circ} \mathrm{C}, 34^{\circ} \mathrm{C}$ and $32^{\circ} \mathrm{C}$ were $80 \%, 76 \%$ and $74 \%$ respectively. The obtained results in figure 1 indicate that decrease in drying temperature leads to decrease in germination percentage.

\section{Effect of drying temperature on germination percentage in Mighty variety seeds}

From the figure 2, it was observed that highest germination was $90 \%$ at drying temperature of $38^{\circ} \mathrm{C}$ whereas lowest germination $85 \%$ was recorded at drying temperature of $32^{\circ} \mathrm{C}$ after undergoing storage of samples for 15 days.

The germination percentages at different temperatures like $36^{\circ} \mathrm{C}, 34^{\circ} \mathrm{C}$ and $32^{\circ} \mathrm{C}$ were $87 \%, 86 \%$ and $85 \%$ respectively. From the obtained results it is clear that decrease in drying temperature leads to decrease in germination percentage, the reason may be prolonged drying. 


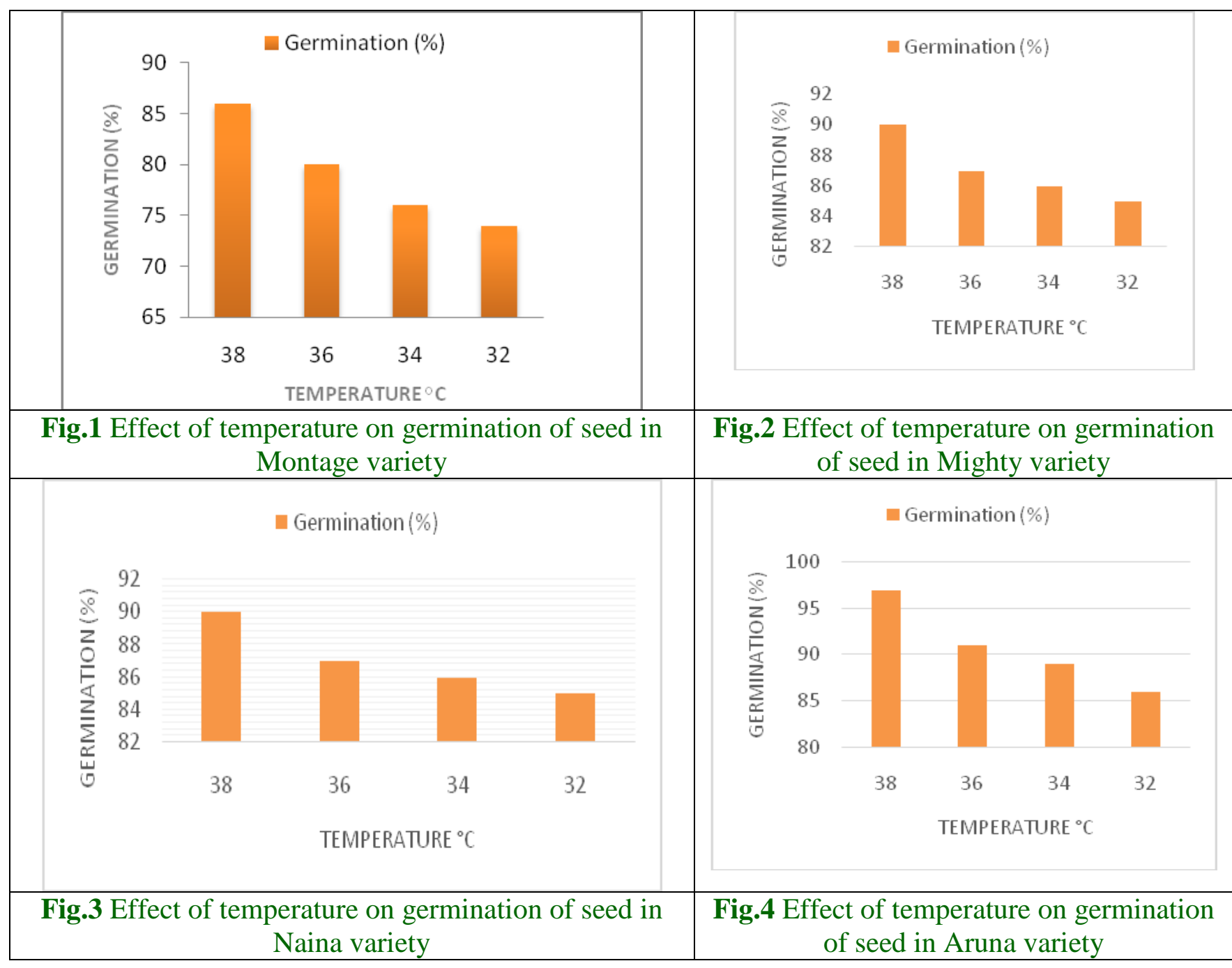

Effect of drying temperature on germination percentage in Naina variety seeds

The result should that highest germination was $97 \%$ at drying temperature of $38^{\circ} \mathrm{C}$ whereas lowest germination $86 \%$ at temperature of $32^{\circ} \mathrm{C}$.

The germination percentages at different temperatures like $36^{\circ} \mathrm{C}, 34^{\circ} \mathrm{C}$ and $32^{\circ} \mathrm{C}$ were $91 \%, 89 \%$ and $86 \%$ respectively.

From the results it can be concluded that, decrease in drying temperature leads to decrease in germination percentage (Fig. 3). The reason maybe prolonged drying.
Effect of drying temperature on germination percentage in Aruna variety seeds

The experiment results revealed that highest germination $93 \%$ was recorded at drying temperature of $38^{\circ} \mathrm{C}$ whereas lowest germination $84 \%$ was recorded at drying temperature of $32^{\circ} \mathrm{C}$.

The germination percentages at different temperatures like $36^{\circ} \mathrm{C}, 34^{\circ} \mathrm{C}$ and $32^{\circ} \mathrm{C}$ were $86 \%, 85 \%$ and $84 \%$ respectively. From the observed results, it was found that decrease in drying temperature leads to decrease in germination percentage; the reason maybe prolonged drying (Fig. 4). 
Vegetable seeds are very sensitive to temperature while drying. If proper temperature is not attained there may be huge loss in terms of quality of seed. The drum drier was used to dry tomato seeds. As per results it was concluded that $25 \% \mathrm{RH}$ and $38^{\circ} \mathrm{C}$ temperature was suitable for an effective drying of all varieties of tomato seeds for good germination. It was observed that prolonged drying because of decrease in drying temperature leads to decrease in germination percentage.

\section{References}

Aworth, O. C., and Olorunda, A. O. (1981). "Towards reducing postharvest losses of perishable fruits and vegetables in Nigeria," in Proceedings of the National Conference in Agriculture, Port Harcourt, Nigeria.

Brunetti L, Fucci F. and La Fianza G. (2004). Un impianto di stagionatura a deumidificazione per assorbimento per alimenti. L Termotecnica; LVII, 4: 6871.

Carcel JA, Garcia-Perez JV, Riera E. And Mulet A. (2007). Influence of high intensity ultrasound on drying kinetics of persimmon. Dry Technol; 25(1): 18593.

Clemente G, Bon J, Garcia-Perez JV. and Mulet A. (2007). Natural convection drying at low temperature of previously frozen salted meat. Dry Technol; 25(11): 1885-91.

Corrêa PC, Horta de Oliveira GH, Machado Baptestini F, Martins Silva Diniz MD. and Almeida da Paixão A. (2012). Tomato infrared drying: modeling and some coefficients of the dehydration process. Chil J Agric Res; 72(2): 262-7

Ekechukwua, O. V. and Nortonb, B. (1999). Review of solar-energy drying systems II: an overview of solar drying technology. Energy Conversion \& Management. 40: 615 \pm 655 .

Georg'e, S., Tourniaire, F., Gautier, H., Goupy, P., Rock, E. and Caris-Veyrat, C. (2011). "Changes in the contents of carotenoids, phenolic compounds and vitamin $\mathrm{C}$ during technical processing and lyophilisation of red and yellow tomatoes," Food Chemistry, vol. 124, no. 4, pp. 1603-1611.

Hernandez-Perez JA, Garcia-Alvarado MA, Trystram G. and Heyd B. (2004). Neural networks for the heat and mass transfer prediction during drying of cassava and mango. Innov Food Sci Emerg Technol; 5(1): 57-64.

Khachik, F., Carvalho, L., Bernstein, P.S., Muir, G. J., Zhao, D.Y. and Katz, N.B. (2002). "Chemistry, distribution, and metabolism of tomato carotenoids and their impact on human health," Experimental Biology and Medicine, vol. 227, no. 10, pp. 845-851.

Khalifa AJN, Al-Dabagh AM. And AlMehemdi WM. (2012). An Experimental Study of Vegetable Solar Drying Systems with and without Auxiliary Heat, International Scholarly Research Network. Renew Energy; 2012: 1-8.

McMinn W.A.M., and Magee TRA. (1999). Principles methods and applications of the convective drying of foodstuffs. Food Bio prod Process; 77(3):175-93.

Nogaya K, Li Y, Jin Z, Fukumuro M, Ando Y. and Akaishi A. (2006). Low temperature desiccant-based food drying system. J Food Eng; 75: 71-7.

Pirasteh, G., Saidur, R., Rahman, S. M. A. and Rahim, N. A. (2014). A review on development of solar drying applications. Renewable and Sustainable Energy Reviews. 31: 133148.

Riahi MH, Trelea IC, Leclercq-Perlat MN, Piacque D. and Corrieu G. (2007). 
Model for changes in weight and dry matter during the ripening of a smear soft cheese under controlled temperature and relative humidity. Int Dairy J; 17(8): 946-53.

Sabongari, S. and Aliero, B.L., (2003). Effects of soaking duration on germination and seedling growth of tomato (Lycopersicum esculentum Mill). African Journal of Biotechnology. Vol. 3 (1), pp. 47-51.

Sacilik. K. (2007). "The thin-layer modelling of tomato drying process," Agriculture
Conspectus Scientifics, vol. 72, no. 4, pp: 343-349.

Shi, J., and Le Maguer, M. (2000). "Lycopene in tomatoes: chemical and physical properties affected by food processing," Critical Reviews in Food Science and Nutrition, vol. 40, no. 1, pp. 1-42.

Vinson, J. A., Hao, Y., Su, X. and Zubik, L. (1998). "Phenol antioxidant quantity and quality in foods: vegetables," Journal of Agricultural and Food Chemistry, vol. 46, no. 9, pp. 36303634.

\section{How to cite this article:}

Perugu Balachandra Yadav, Guda Prasanna, Gadhe Shruthi and Srinivasa Rao, A. 2018. Standardization of Temperature for Effective Germination of Tomato Seeds Using Drum Dryer. Int.J.Curr.Microbiol.App.Sci. 7(09): 414-419. doi: https://doi.org/10.20546/ijcmas.2018.709.051 